\title{
Game for Food Ingredients Grouping Improving Student's Understanding of Sources of Nutrition
}

\author{
Muhammad Ridho Nugroho; Badeni; Fitri April Yanti; Muhammad Kristiawan \\ University of Bengkulu, Indonesia \\ http://dx.doi.org/10.18415/ijmmu.v8i9.2959
}

\begin{abstract}
According to the 2018 Global Nutrition Report, the hab it of school-aged children choosing meals is still bad over the world. Around $30.3 \%$ of school-aged children do not eat fruit daily, whereas $43.7 \%$ consume soda daily. This study aims to increase student's knowledge about the material sources of nutrients in food through a game of grouping foodstuffs using a food model with a constructivist learning approach designed by the author. The participants in this study were 33 SDIT Raudhatul Jannah Lubuklinggau grade 4,5 and 6 students. The method used in this study uses an experimental design with a pre and post-test approach without control. Total sampling was used for sampling, and the Wilcoxon test was used for interpretation. This study was completed in March of 2021. Research results show a p-value of $.000(<.05)$, indicating that students' awareness of the material sources of nutrients in food increased after they were given a game grouping food ingredients using a food model. It is recommended that educators be able to provide students with learning resources that take a constructivist approach, such as games that actively engage students, so that students' awareness can be developed through direct experiences.
\end{abstract}

Keywords: Food Grouping; Food Model; Source of Nutrients

\section{Introduction}

Some elementary school students do not understand the concept of sources of nutrients contained in food. In the integrated thematic textbook for grade 5 SD with the title "Healthy Food" in sub-theme 2: The Importance of Healthy Food for the Body, there is learning material about the sources of nutrients contained in food. The importance of knowing the sources of nutrients contained in food ingredients is so that students can choose nutritionally balanced food according to the portion so that they can change their diet to a healthy diet containing carbohydrates, protein, fat, vitamins, and minerals according to their needs.

Children need adequate nutrition so that their growth can be achieved optimally. Fulfillment of appropriate nutrition allows children to grow optimally because in this phase children experience rapid growth (H. HuyeE, et.al 2016). In general, the source of nutrients needed by children is divided into carbohydrates, proteins, fats, vitamins, and minerals in their respective proportions. The proportion of nutrients from the total calorie requirement for carbohydrates (charcoal hydrate) is $60-70 \%, 20-25 \%$ for fat, and $10-15 \%$ for protein. (Komariah, 2017).

Sources of carbohydrates are found in staple food ingredients such as rice, corn, wheat, bread, and tubers, protein sources are found in side dishes such as fish, chicken, meat, eggs, tofu, and tempe, sources of fat are found in oil and margarine, while sources of vitamins and minerals are found in the 
types of vegetables and fruits, setting the right food portions according to children's nutritional needs can make children grow and develop properly and can support their performance in school.

To make it easier for students to understand the material of food ingredients according to their nutritional sources, and innovation is needed, one of which is through games. This game is a real game using a food model as a tool and involves students playing an active role in the game. School-age children tend to act like to play and ask a lot of questions so that the method chosen allows children to play a full role in learning so that children appreciate the knowledge and skills acquired in their efforts. Various methods that encourage children's participation and involvement in learning activities include games, group discussions, and demonstrations. (Gambir \& Nopriantini, 2018)

Health education for children can be provided in many ways, one of which is through the media of games, so that children can be interested in learning about health. The use of game media is very strong in creating a narrative and rich world to achieve educational goals (Barab, S.A., Gresalfi, M. \& IngramGoble, 2010). Nutrition education for school children must be provided in an appropriate manner and media to attract children's attention to make it easier for children to receive information about nutrition. (Athira Demitri, Ernawati Nasution \& Evawany Aritonang 2015)

Nutrition education for children needs special attention because it is different from nutrition education for adolescents or adults. Ideally, nutrition education for children is carried out in a pleasant atmosphere and using media that is easily accepted (Suhardjo, 2003).

In this study, the type of game designed is to involve students directly in the game through the constructivism learning approach, constructivism is a constructive theory, building in terms of ability, understanding, in the learning process. Because by having a constructive nature, it can be expected that the activeness of students will increase their intelligence. (Suparlan, 2019)

According to Yuliatiningsih, et.al in Sujarwanto (2016) there are 4 learning steps for the constructivism model, namely:

\section{Stages \\ Early Knowledge Stage}

Exploration Stage

Discussion and Concept

Explanation Stage

Concept Development and Application Stage

\section{Table 1: Constructivism Learning Steps}

Steps

at this stage, students are encouraged to express their initial knowledge of the concepts to be studied. The teacher fishing with questions related to the phenomena of everyday life related to the concepts to be discussed at this stage, students are invited to find concepts through investigation, data collection, and data interpretation through an activity designed by the teacher. Exploration activities can be in the form of observations, experiments, discussions, questions, and answers, looking for information through books, or surfing the internet in groups

at this stage, students provide explanations and solutions based on the results of their observations. The teacher's job is to provide reinforcement not to provide information. Thus the students themselves build new understandings of the concepts being studied. If the conception (initial knowledge) is correct, then students do not have any doubts about the conception. If the conception (initial knowledge) is wrong, then exploration will be a bridge between students' conceptions and new concepts

at this stage, the teacher tries to create a learning climate that allows students to apply their understanding of the concept. The teacher raises the contents of environmental issues that can be solved through understanding the concepts that have been obtained. Thus, it is hoped that the concepts he learns will be meaningful 
Learning carried out in this activity is carried out by using the food model media as a learning tool combined with a game of grouping food ingredients according to their nutritional source. The stages of the game are carried out following the constructivism learning theory, the initial steps taken are as follows:

Initial knowledge stage: First students are given knowledge/concepts about the benefits of a balanced nutritious diet, namely that the human body requires a balanced intake of nutrients both in types and in certain levels as energy, building blocks, and body metabolism regulators.

Exploration stage: Students are introduced to various types of food ingredients through the media food model to find out what sources of nutrients are contained in these food ingredients. Types of food ingredients are grouped into 4 parts, namely sources of carbohydrates, proteins, fats, vitamins, and minerals. Among the types of food models used are:

\section{Table 2: Types of Food Models are grouped according to their nutritional sources}

\begin{tabular}{llll}
\multicolumn{1}{c}{ Carbohydrate } & \multicolumn{1}{c}{ Protein } & \multicolumn{1}{c}{ Fat } & \multicolumn{1}{c}{ Vitamins and Minerals } \\
Rice & Fish & Vegetable oil & Mango \\
Corn & Meat & Margarine & Orange \\
White bread & Egg & & Banana \\
Tubers & Tofu & & Spinach \\
Wheat & Tempe & & Sawi \\
& & & Cabbage
\end{tabular}

Discussion stage and concept explanation: Then students are asked to discuss the functions and uses of each food ingredient for the body. As an exemplary student, A explained the function of vegetable food ingredients.

Discussion stage and concept explanation: Then students are asked to discuss the functions and uses of each food ingredient for the body. For example, student A explained the function of vegetable food as a source of vitamins and minerals that function as substances that regulate the body's metabolism.

Development and concept application stages: Students are invited to play games about grouping food ingredients according to their nutritional sources in the following ways:

1. Each student randomly picks 3 food models

2. Then each student is asked to explain the source of the nutrients contained in the food model that they have taken randomly

3. Each student is asked to enter the food model into the basket which has been grouped into carbohydrates, proteins, fats, vitamins, and minerals

4. Then an evaluation is carried out on the basket of food grouping according to the source of nutrients to see if there are students who are still wrong to enter the food model according to the basket

Through these game students are trained to build constructive knowledge starting from knowing the benefits of nutrients for the body, recognizing food ingredients as sources of nutrients, explaining the function of food ingredients according to their nutritional sources, and then knowing and classifying food ingredients according to their nutritional sources. So that students' knowledge will be awakened about the material provided through direct knowledge and application through games. 


\section{Research Method}

This type of research is quantitative research with experimental research design with pre and post-test approaches without control. The effectiveness of the treatment was assessed by comparing the pre-test and post-test scores. The sample in this study was observed first before being given treatment, then after being given treatment the sample was observed again. Children's knowledge about the sources of nutrients in food is measured by the question sheets given before and after the food grouping game intervention using a food model. The pre-test, post-test, and game intervention activities were carried out for three days.

The subjects in this study were all students of grades 4,5 and 5 SDIT Raudhatul Jannah Lubuklinggau because they are capable enough to play the game. Totaling 33 students with a total sampling technique. Data collection techniques are documentation, interview, and observation. Statistical analysis used the Wilcoxon test with the SPSS program.

\section{Result and Discussion}

The gender characteristics of students as respondents per class can be seen in the following table:

Table 3: Distribution of Respondents by Gender

\begin{tabular}{ccccccc} 
Class & \multicolumn{9}{c}{ Gender } & Amount & $\%$ \\
& $\mathrm{M}$ & $\%$ & $\mathrm{~F}$ & $\%$ & & \\
IV & 3 & $9,09 \%$ & 10 & $30,30 \%$ & 13 & $30,39 \%$ \\
V & 6 & $18,18 \%$ & 4 & $12,12 \%$ & 10 & $30,30 \%$ \\
VI & 5 & $15,15 \%$ & 5 & $15,15 \%$ & 10 & $30,30 \%$ \\
& 14 & $42,42 \%$ & 19 & $57,57 \%$ & 33 & $100 \%$
\end{tabular}

Table 3 shows the number of male respondents by 14 people (42.42\%) and 19 respondents with female gender $(57.57 \%)$.

Before being given intervention in the form of a game grouping food ingredients using a food model, students were given pretest questions to measure students' initial knowledge about the sources of nutrients in food with the following pre-test results:

Table 4: Student Pre Test Results

$\begin{array}{ccc}\text { Score Interval } & \text { Amount } & \text { Percentage (\%) } \\ 20-50 & 15 & 45,45 \% \\ 51-70 & 12 & 36,36 \% \\ 71-90 & 6 & 18,18 \% \\ 91-100 & 0 & 0 \% \\ & 33 & 100 \%\end{array}$

Table 4 shows that before being given the intervention in the form of a game grouping food ingredients according to their nutritional sources using a food model, it is known that the pre-test results of 15 students (45.45\%) got a score between 20-50, as many as 12 students (36.36\%) got Score scores between 51-70, as many as 6 students (18.18\%) get a score between $71-90$, while students who get a score of 91-100 do not exist.

Then after the intervention, students are given post-test questions to measure the increase in students' knowledge about the sources of nutrients in food with the following post-test results: 
Table 5: Student Post Test Results

$\begin{array}{ccc}\text { Score Interval } & \text { Amount } & \text { Percentage }(\%) \\ 20-50 & 1 & 3,03 \% \\ 51-70 & 4 & 12,12 \% \\ 71-90 & 17 & 51,52 \% \\ 91-100 & 11 & 33,33 \% \\ & 33 & 100 \%\end{array}$

Table 5 shows that after being given intervention in the form of a game grouping foodstuffs according to their nutritional sources using a food model, it is known that the post-test results of 1 student (3.03\%) get a score between 20-50, as many as 4 students (12.12\%) Getting a score of 51-70, 17 students (51.52\%) got a score between 71-90, while 11 students (33.33\%) had a score of 91-100.

Before the analysis test is carried out, the data normality test is conducted first with the following results:

Table 6: Data Normality Test

Test of Normality

\begin{tabular}{lrccrcl} 
& \multicolumn{2}{c}{ Kolmogorov-Smirnov $^{\mathrm{a}}$} & \multicolumn{3}{c}{ Shapiro-Wilk } \\
& Statistic & df & Sig. & Statistic & df & Sig. \\
Prestest & 0,123 & 33 & $0,200^{*}$ & 0,964 & 33 & 0,331 \\
Posttest & 0,197 & 33 & 0,002 & 0,827 & 33 & 0,000
\end{tabular}

Table 6 shows that the results of the data normality test using the Shapiro-Wilk test in the pre-test show that the value of $p=(0.331)>(0.05)$, and the post-test shows that the value of $p=(0.000)<(0.05)$ so that it can be it was concluded that the data were not normally distributed. Because the data were not normally distributed, the analysis was carried out using the Wilcoxon test.

Table 7: Wilcoxon test

Test Statistics

\begin{tabular}{l}
\hline Z \\
\hline Asymp. Sig. (2-tailed) \\
a. Wilcoxon Signed Ranks Test \\
b. Based on negative ranks.
\end{tabular}

posttest - pretest

Based on the results of the Wilcoxon test analysis, it was obtained that the value of $p=0.000$ $<0.05$ means that there is an effect of giving food grouping games using the food model on increasing children's knowledge about sources of nutrients in food.

From the table above, it is known that most of the students' pretest scores before being given the game were at a score of 20-50 and none of the students had a score of 90-100, this shows that most of the students did not know the source of nutrients in food. Then after being given the game intervention, the students' post-test results increased, that is, more than half of the students had post-test scores between 71-90 and 33.33 percent of the students had a score of 91-100. The results of the analysis using the Wilcoxon test showed that there was an effect of giving games on an increase in student knowledge. 
The increase in students' knowledge after being given intervention in the form of the game is because the constructivism method in the game experienced directly by students makes it easy for them to understand the material that has been taught.

\section{Nutrition Education for school children}

The increase in children's attitudes about nutrition may also be due to increased children's knowledge. Increasing nutritional knowledge in children through nutrition education will help children's attitudes and will affect children's habits in choosing healthy foods. (Tiara, Dife Nur, Syarief, Osman, Pramintarto, Gurid, Mutiyani, Mira \& Selviyanti, 2019)

Nutrition education is an effective way of increasing nutritional knowledge and attitudes, as well as healthy eating behavior. Various forms of nutrition improvement programs targeting children, families, teachers, and school settings have been implemented in many developed countries (Cheng, G., Yang, F., Xiong, F., Zhao, L., Zhang, L., \& Wang, Y, 2020). An effective healthy lifestyle education approach fosters positive behavior change among children and families through face-to-face and online programs (Antine, S., Horset, A. M. L., Heiden, P., \& Salazar, G. (2020)

The lack of material on the nutrition provided in elementary schools makes students have a low understanding of the sources of nutrients found in food. A study conducted by Hedaoo, RP, Kabra, P., \& Gavaravarapu, S. M (2021) using a nutritainment module based on an edutainment approach that aims to increase the nutritional knowledge score of adolescents states that there is a need for special sessions for nutrition education in the school curriculum so that the necessary skills can be better inculcated through experiential learning and an edutainment approach so that effective results are obtained.

According to Hapsari in Nugroho (2018), six to fourteen years of age is an adequate age for children to get nutritional education because at these age children begin to mature sexually and mature for learning as well as an intellectual period. From this age range, the age of eleven years is the most appropriate age to get nutrition education because at that age the child is in a formal operational stage, which can think abstractly, reason logically, and draw conclusions from the available information. (Patterson, 2008)

\section{The importance of healthy food for school children}

Optimal nutritional intake, both in terms of quantity and quality, is very important for optimal growth and development. For that, our diet needs to be improved towards the consumption of balanced nutrition. Balanced nutrition is the composition of daily food containing nutrients in the type and amount according to the body's needs. One of the pillars of balanced nutrition is; Consuming a wide variety of foods. The consumption of a variety of foods is very important because there is no single type of food that contains all the types of nutrients the body needs to stay healthy, except for breast milk (ASI). Breast milk contains all the nutrients the body needs, but only for babies born to 6 months of age. In addition, interactions between nutrients occur in the body, for example, certain nutrients require other nutrients to be circulated or digested by the body. For example, digestion of carbohydrates, fats, and protein requires B vitamins which can be found in green leafy vegetables. (Rachmi, CN, Wulandari, E., Kurniawan, H., Wiradnyani, LAA, Ridwan, R., \& Akib, T. C, 2019)

Many of the school children have unhealthy eating habits due to the lack of children's knowledge about nutritious and balanced food. The trend of unhealthy eating habits of children around the world has led many researchers to have explored the practice of preparing healthy food as a health promotion habit. The straightforward preparation of healthy meals appears to be promising among children, as it focuses on concrete experiences in creating positive attitudes towards nutrition. (Choon Ming Ng, Satvinder Kaur, Hui Chin Koo \& Firdaus Mukhtar, 2020)

School-age is filled with dense activities, for that students need sufficient carbohydrate intake as a source of energy to support students' daily activities. Carbohydrates are one of the nutrients needed by 
humans to produce energy for the human body. Carbohydrates as nutrients are the names of groups of organic substances that have different molecular structures, although there are similarities in terms of chemistry and function. All carbohydrates consist of the elements Carbon $(\mathrm{C})$, hydrogen $(\mathrm{H})$, and oxygen (O). (Siregar, 2014)

One source of nutrients that are also very much needed by school-age children is protein. Protein is a building block for the body. Because protein functions in the formation of new cells and maintain cells in the body. So proteins function like the bricks that make up a house. In addition, protein also plays a role in the work of enzymes, hormones, and maintains immunity. Compared to other nutrients, protein is the largest part of the body's tissues. Proteins are made of various amino acids. Our bodies cannot produce all the amino acids it needs, so they must be obtained from the food we eat, whether they come from animals (animal protein) or plants (vegetable). (Rachmi et al., 2019)

Vitamins and minerals function to maintain organ function and the body's metabolic processes. According to the results of basic health research in 2018, the consumption of vegetables and fruit in Indonesians is still below the recommended amount. Vegetables and fruits are a source of vitamins, minerals, and fiber needed by adolescents in the process of growth and disease prevention. For example, vitamin D and vitamin A are needed for growth, while folic acid, vitamin B6, and vitamin B12 are needed to prevent heart disease. (Rachmi et al., 2019)

\section{The role of family and teachers}

Family is a key element in shaping and influencing behavior related to children's lifestyles by actively involving the family and being committed to promoting nutrition and physical activity patterns in children (Al Yazeedi, B., Berry, DC, Crandell, J., \& Waly, M, 2021). To meet the nutritional needs of students, a large role is needed from parents and teachers. Parents have a role in fulfilling children's nutrition at home, parents, especially mothers, should know the ability to fulfill children's nutrition so that children get the right nutrition according to their needs. The important role of a mother at home in providing nutritious food to children is the main thing.

Teachers are also expected to provide more intensive assistance and role models of independence in solving problems according to children's abilities. so that all of its potentials can be increased and an independent person can be created. Teachers are expected to work together with parents so that the development of children at home can continue in school supported by routine activities for independent study. (Lydia, M., Nina, NK, Wayan, D., Rambat Nur, S., \& Lutfi Firdaus, M, 2018)

A literature study conducted by Cotton, W., Dudley, D., Peralta, L., \& Werkhoven, T (2020) shows that teaching nutrition education in primary schools by qualified teachers can make an important contribution to children's knowledge and eating habits. Small and medium effect sizes suggest that careful, evidence-based decisions need to be made by policymakers and pedagogies regarding the teaching strategies used when delivering nutrition education programs to primary-age students.

\section{Conclusion and Suggestion}

This study concludes that there is an increase in student's knowledge about the sources of nutrients found in food after being given intervention in the form of a game of grouping food ingredients using a food model. It is recommended that educators be able to provide learning materials with a constructivist approach to students through direct application through games that involve students so that students' knowledge can be built through direct experiences they experience. For further research, games can be developed in Android-based games to train students in classifying food ingredients according to their nutritional sources. 


\section{References}

Al Yazeedi, B., Berry, D. C., Crandell, J., \& Waly, M. (2021). Family Influence on Children's Nutrition and Physical Activity Patterns in Oman. Journal of Pediatric Nursing, 56, e42-e48. https://doi.org/10.1016/j.pedn.2020.07.012.

Antine, S., Horset, A. M. L., Heiden, P., \& Salazar, G. (2020). Experiential children's s nutrition education: Growing strong bodies and healthy minds. 16, 340-341. https://doi.org/10.1016/j.explore.2020.06.007.

Athira Demitri, Ernawati Nasution, E. A. (2015). Pengaruh Pendidikan Gizi Tentang Pola Makan Seimbang Melalui Game Puzzle Terhadap Peningkatan Pengetahuan Anak SDN 067690 Kota Medan. http://download.garuda.ristekdikti.go.id/article.php?article=1424840\&val=4108\&title.

Barab, S.A., Gresalfi, M. \& Ingram-Goble, A. (2010). Transformational Play: Using Games to Position Person, Content, and Context. Educational Researcher, 39(7), 525-536. https://www.learntechlib.org/p/51677/.

Cheng, G., Yang, F., Xiong, F., Zhao, L., Zhang, L., \& Wang, Y. (2020). Comparison of nutrition education policies and programs for children in China and other selected developed countries. Global Health Journal, 4(3), 72-78. https://doi.org/10.1016/j.glohj.2020.08.002.

CJ., P. (2008). Child Development. New York. McGraw Hill.

Cotton, W., Dudley, D., Peralta, L., \& Werkhoven, T. (2020). The effect of teacher-delivered nutrition education programs on elementary-aged students: An updated systematic review and meta-analysis. Preventive Medicine Reports, 20(April), 101178. https://doi.org/10.1016/j.pmedr.2020.101178.

Gambir, J., \& Nopriantini, N. (2018). Penerapan Model Edukasi Gizi terhadap Perilaku Sarapan pada Anak Sekolah Dasar. Jurnal Vokasi Kesehatan, 4(2), 85. https://doi.org/10.30602/jvk.v4i2.133.

H. HuyeE. Molaison R. Kingston. (2016). Poster Session : Wellness and Public Health; Using Grocery Store Tours Led By Dietetic Interns to Increase College Students' Fruit and Vegetable Consumption. Journal of the Academy of Nutrition and Dietetics, 116(9), A35. https://doi.org/https://doi.org/10.1016/j.jand.2016.06.119.

Hedaoo, R. P., Kabra, P., \& Gavaravarapu, S. M. (2021). “ Nutritainment " - A Nutrition Education Module for Indian Adolescents. Journal of Nutrition Education and Behavior, 53(2), 187-190. https://doi.org/10.1016/j.jneb.2020.11.002.

Lilis Komariah. (2017). Klasifikasi Olahraga Dan Proses Pemecahan Energi Dalam Tubuh. http://file.upi.edu/Direktori/FPOK/JUR._PEND._OLAHRAGA/195906281989012LILIS_KOMARIYAH/MODUL_IKOR.pdf.

Lydia, M., Nina, N. K., Wayan, D., Rambat Nur, S., \& Lutfi Firdaus, M. (2018). The Influence of Parents Parenting Style Towards The Independence Of Preschool Children. Indian Journal of Science and Technology, 11(30), 1-6. https://doi.org/10.17485/ijst/2018/v11i30/128245.

Ng, C. M., Kaur, S., Koo, H. C. K. \&, \& Mukhtar, F. (2020). Nutrition-related outcomes of children's involvement in healthy meal preparation: a scoping review protocol. JBI Database of Systematic Reviews and Implementation Reports, 18(3), 534-542. https://doi.org/10.11124/JBISRIR-D-1900209.

Nugroho, A. (2018). Pengaruh Media Pendidikan Gizi ( Komik) terhadap Peningkatan Pengetahuan dan Perubahan Berat Badan pada Anak Sekolah Dasar dengan Obesitas. 9(April), 57-63. https://doi.org/DOI: http://dx.doi.org/10.26630/jk.v9i1.746. 
Nurhamida Sari Siregar. (2014). Karbohidrat. Jurnal Ilmu Keolahragaan, 13(2), 38-44. https://doi.org/DOI : 10.24114/jik.v13i2.6094.

Rachmi, C. N., Wulandari, E., Kurniawan, H., Wiradnyani, L. A. A., Ridwan, R., \& Akib, T. C. (2019). Buku Panduan Siswa AKSI BERGIZI. Kemenkes RI, 1-188.

Suhardjo. (2003). Berbagai Cara Pendidikan Gizi. Jakarta. Bumi Aksara.

Sujarwanto, -. (2016). Penerapan Model Pembelajaran Konstruktivisme Pada Materi Ciri-Ciri Mahluk Hidup Di Kelas III a Sd Negeri Keputran. Mimbar Sekolah Dasar, 3(1), 69-80. https://doi.org/10.17509/mimbar-sd.v3i1.2357.

Suparlan, S. (2019). Teori Konstruktivisme dalam Pembelajaran. Islamika, 1(2), 79-88. https://doi.org/10.36088/islamika.v1i2.208.

Tiara, Dife Nur, Syarief, Osman, Pramintarto, Gurid, Mutiyani, Mira, Selviyanti, S. S. (2019). Pendidikan gizi menggunakan cerita bergambar terhadap pengetahuan dan frekuensi konsumsi sayur buah pada siswa. Jurnal Riset Kesehatan Poltekkes Kemenkes Bandung, 165-172. https://doi.org/https://doi.org/10.34011/juriskesbdg.v11i1.670.

\section{Copyrights}

Copyright for this article is retained by the author(s), with first publication rights granted to the journal.

This is an open-access article distributed under the terms and conditions of the Creative Commons Attribution license (http://creativecommons.org/licenses/by/4.0/). 